\title{
Recent advances in the prevention of preterm birth [version 1;
}

\section{peer review: 2 approved]}

\author{
Jeff A Keelan (D), John P Newnham
}

Division of Obstetrics \& Gynaecology, School of Medicine, University of Western Australia King Edward Memorial Hospital, Perth, Australia

V1 First published: 18 Jul 2017, 6(F1000 Faculty Rev):1139

https://doi.org/10.12688/f1000research.11385.1

Latest published: 18 Jul 2017, 6(F1000 Faculty Rev):1139

https://doi.org/10.12688/f1000research.11385.1

\section{Abstract}

Preterm birth (PTB) remains a major obstetric healthcare problem and a significant contributor to perinatal morbidity, mortality, and longterm disability. Over the past few decades, the perinatal outcomes of preterm neonates have improved markedly through research and advances in neonatal care, whereas rates of spontaneous PTB have essentially remained static. However, research into causal pathways and new diagnostic and treatment modalities is now bearing fruit and translational initiatives are beginning to impact upon PTB rates. Successful PTB prevention requires a multifaceted approach, combining public health and educational programs, lifestyle modification, access to/optimisation of obstetric healthcare, effective prediction and diagnostic modalities, and the application of effective, targeted interventions. Progress has been made in some of these areas, although there remain areas of controversy and uncertainty. Attention is now being directed to areas where greater gains can be achieved. In this mini-review, we will briefly and selectively review a range of PTB prevention strategies and initiatives where progress has been made and where exciting opportunities await exploitation, evaluation, and implementation.

Keywords

Preterm birth, progesterone therapy, PTB prevention

\section{Open Peer Review}

Approval Status

1 2

version 1

18 Jul 2017

Faculty Reviews are review articles written by the prestigious Members of Faculty Opinions. The articles are commissioned and peer reviewed before publication to ensure that the final, published version is comprehensive and accessible. The reviewers who approved the final version are listed with their names and affiliations.

1. Martijn A Oudijk, Academic Medical Centre, Amsterdam, The Netherlands

2. Louis Muglia, Cincinnati Children's Hospital Medical Center, Cincinnati, OH, USA

University of Cincinnati College of Medicine,

Cincinnati, OH, USA

Any comments on the article can be found at the end of the article. 
Corresponding author:Jeff A Keelan (jeff.keelan@uwa.edu.au)

Competing interests: The authors declare that they have no competing interests.

Grant information: The author(s) declared that no grants were involved in supporting this work.

Copyright: $\odot 2017$ Keelan JA and Newnham JP. This is an open access article distributed under the terms of the Creative Commons Attribution License, which permits unrestricted use, distribution, and reproduction in any medium, provided the original work is properly cited.

How to cite this article: Keelan JA and Newnham JP. Recent advances in the prevention of preterm birth [version 1; peer review: 2 approved] F1000Research 2017, 6(F1000 Faculty Rev):1139 https://doi.org/10.12688/f1000research.11385.1

First published: 18 Jul 2017, 6(F1000 Faculty Rev):1139 https://doi.org/10.12688/f1000research.11385.1 


\section{Introduction}

Preterm birth (PTB) is defined as birth at $>20$ and $<37$ completed weeks of gestation. Despite decades of research, PTB remains a major obstetric healthcare problem of global significance ${ }^{1,2}$. PTB is the single major cause of death and disability in children up to 5 years of age in the developed world and the leading single cause of global perinatal mortality and morbidity ${ }^{3-5}$; approximately 15 million babies are born preterm each year worldwide, and a million of these children $d_{i} e^{5,6}$. Preterm infants are also at significantly greater risk of serious perinatal complications ${ }^{7-10}$. While many children born preterm lead a normal and healthy life, a significant proportion experience life-long disability and health issues ${ }^{11}$. The impact on individuals, families, and society are considerable, as are the healthcare costs associated with perinatal care and life-long disability ${ }^{1,5,9,12}$.

In developed countries, about $30 \%$ of preterm deliveries are iatrogenic, with the remainder being spontaneous, either with intact membranes or following preterm pre-labour rupture of membranes (PPROM) $)^{1,2}$. Many different causes of spontaneous PTB (sPTB) have been identified, the most common of which in singleton pregnancies are likely to be intrauterine inflammation (IUI)/ intrauterine infection, placental malperfusion, or other placental abnormalities ${ }^{1,2,7,13,14}$. Inflammation appears to be a common mechanism underpinning multiple aetiologies ${ }^{15-17}$. While placental malperfusion pathologies are very common in singleton preterm deliveries, effective strategies to treat or prevent them-other than the administration of low-dose aspirin as anti-coagulant therapy ${ }^{18-20}$-have not been developed or tested. The causal significance of such pathologies is also uncertain. This is a relatively untapped area that deserves significant research investment ${ }^{18,21}$.

As is the case for most healthcare problems, prevention is better than cure $^{22}$. Successful prevention of PTB requires a multifaceted approach, combining public health and educational programs, lifestyle modification, optimisation of obstetric healthcare, effective prediction and diagnostic modalities, and the application of effective, targeted interventions ${ }^{23}$. Preconception interventions in the form of weight reduction, nutritional supplementation, pharmaceutical management, and smoking cessation, etc. have the potential to make a significant impact on PTB rates ${ }^{24-26}$, although implementation and access remain significant barriers ${ }^{24,25,27}$.

In the following paragraphs, we will provide a brief and selective overview of the recent advances in SPTB prevention, with a perspective on the opportunities for gains in the short and medium term.

\section{Recent advances}

The benefits and limitations of progesterone therapy

A number of randomised controlled trials and meta-analyses have been conducted on two particular interventions used clinically for PTB prevention: progesterone therapy and cervical cerclage ${ }^{28}$. Despite the controversy over the effectiveness of these interventions in recent years, some clarity is emerging. Jarde et al., in a recently published network meta-analysis, concluded that progesterone was more effective than cerclage for primary prevention of PTB in high-risk women with a singleton pregnancy ${ }^{29}$. This is consistent with a recent patient-level meta-analysis, which concluded that cervical cerclage lacked demonstrable efficacy in women with a shortened cervix $(<25 \mathrm{~mm})^{30}$, although this may depend on previous PTB status. On the other hand, progesterone therapy was found to significantly decrease rates of PTB at $<34$ weeks (OR $0.44)$ and $<37$ weeks (OR 0.58) and neonatal death (OR 0.50) ${ }^{29}$. Romero et al. had earlier come to similar conclusions following their own re-analysis of published trials, supporting previous analyses of benefits and risks ${ }^{31}$. Both of these meta-analyses included the OPPTIMUM trial ${ }^{32}$, which failed to find a significant benefit of progesterone, although it reported some favourable trends. Importantly, the longer-term benefits of progesterone treatment to the child still remain to be proven ${ }^{32-34}$, and some authors have raised concerns regarding adverse effects on the developing brain ${ }^{35,36}$. This remains a major area of clinical uncertainty in need of solid, unambiguous data.

Progesterone's effectiveness in women with a multiple pregnancy appears much less significant than in singleton pregnancies ${ }^{37-40}$, although the evidence that it lacks efficacy in this group ${ }^{41}$ has recently been challenged ${ }^{42}$; consensus on this topic remains elusive. The findings of several studies, including a recently published large trial, suggests that vaginal progesterone is more effective than intramuscular $17 \alpha$-hydroxyprogesterone (17-OHP), although this may depend on various risk factors and aetiology $37,38,43-47$. Vaginal progesterone is certainly a much cheaper option. There is some evidence of increased risk of developing gestational diabetes with 17-OHP treatment ${ }^{43}$.

One limitation of progesterone therapy is that it is applicable to only a small percentage of pregnant women (primarily those with a shortened cervix and those with a history of previous SPTB), so its net benefits on a population basis are limited ${ }^{4,42,48}$. Nevertheless, several studies have now confirmed the feasibility of conducting population-based cervical screening programs ${ }^{28,34,49,50}$ and have concluded that the cost-effectiveness of such programs combined with progesterone therapy is favourable $\mathrm{e}^{49,51-54}$, although they would clearly be improved if the effectiveness of interventions could be increased ${ }^{55}$.

We have some insight into how the effectiveness and response rates to progesterone therapy could be improved. Several lines of evidence suggest that inflammation in the cervix is required for effective vaginal progesterone treatment, which appears to work at least in part through an anti-inflammatory mechanism ${ }^{45,48,56-58}$. Markers of cervical inflammation could, therefore, be employed to target therapy to those at highest risk ${ }^{59,60}$. Alternatively, maternal blood-based tests ${ }^{61}$ may be useful in identifying responders and non-responders as well as women with systemic inflammatory activation ${ }^{62-64}$.

\section{Cervical length screening}

Measurement of the length of the cervix in mid-pregnancy using transvaginal ultrasound has been shown to be able to predict PTB with clinically useful reliability ${ }^{65-68}$. For PTB prediction, the sensitivity of a cervical length of $<25 \mathrm{~mm}$ in women with a singleton gestation (no prior PTB) is $\sim 40 \%$, with a negative predictive value of $97 \%$; in women with a prior PTB, the sensitivity approaches $70 \% 6 \%$. The risk of PTB increases as cervical length decreases; in women with a cervix length of $<15 \mathrm{~mm}$ the risk of sPTB approaches $50 \%{ }^{68}$. 
A limitation of screening for shortened cervix is its low prevalence, ranging from 0.9 to $2.3 \%$ depending on the population and the cutoff employed $(<15,20 \text {, or } 25 \mathrm{~mm})^{54,70}$. It has been calculated that screening 10,000 asymptomatic pregnancies followed by progesterone therapy would likely prevent only 60 cases of $\mathrm{PTB}^{71}$ and 16 deliveries at $<33$ weeks ${ }^{22}$. Regions where PTB rates are low are likely to see even less benefit of screening and treatment. Nevertheless, given the potential mortality and morbidity of PTB, an investment in preventing this number of cases may indeed be warranted.

Some new sonographic approaches to cervical screening appear promising, however. Dziadosz et al. recently described the predictive performance of uterocervical angle measurement at 16-23 weeks' gestation ${ }^{72}$ They reported that an angle of $\geq 95^{\circ}$ was significantly associated with SPTB at $<37$ weeks, with a sensitivity of $80 \%$ and a negative predictive value of $95 \%$, while an angle of $\geq 105^{\circ}$ predicted SPTB at $<34$ weeks (sensitivity $81 \%$; negative predictive value $99 \%$ ). This considerably outperformed standard transvaginal cervical length measurement.

Several groups have investigated the use of cervical ultrasound elastography to predict SPTB with and without cervical length assessment ${ }^{73,74}$. Two different approaches for quantitative determination of the physical properties of the pregnant cervix have been developed: strain elastography and shear wave elastography ${ }^{73}$. In a small pilot study, a combination of strain elastography ratio and cervical length measurement was reported to greatly increase predictive performance, achieving an AUC of $0.88^{75}$. These advances open up the possibility of significant improvements in risk prediction and also response to treatment. However, they are still likely to predict only a small fraction of women who deliver preterm.

\section{PTB prevention programs and specialist clinics}

A number of dedicated PTB prevention clinics have been established and evaluated over recent years. The first evaluation of such a program was the West Los Angeles PTB Prevention Project in the 1990s, which involved eight prenatal county clinics in California ${ }^{76}$. The intervention, which included maternal education and increased clinic attendances, was reported to have achieved a significant $19 \%$ reduction in the PTB rate. More recent PTB prevention clinics have employed additional diagnostics and therapeutic interventions, including assessment of vaginal microbiology, fibronectin testing, ultrasound detection of shortened cervix, antibiotic use, progesterone therapy, cervical cerclage, and Arabin cervical pessaries. Most clinics treat women with a history of PTB or recurrent mid-pregnancy loss, previous PPROM, or previous loop excision or cone biopsy of the cervix. Manuck et al. found that in women who attended a dedicated PTB prevention clinic, recurrent PTB was considerably reduced $(48.6 \% \text { versus } 63.4 \%)^{77}$, as was the rate of composite neonatal morbidity $(5.7 \% \text { versus } 16.3 \%)^{76}$. The clinic consisted of three standardised clinic attendances, with routine administration of intramuscular 17-OHP and sonographic measurement of cervical length.

A UK survey of 23 dedicated PTB prevention clinics revealed considerable heterogeneity in protocols and practices, recommending improved networking, coordination, and consistency in referral criteria $^{78}$. PTB prevention clinics have now become an accepted part of antenatal care in many countries, making a systematic evaluation of their effectiveness very difficult ${ }^{79}$. However, a recent review of the effectiveness of PTB prevention clinics found three trials with suitable data for analysis; a very modest, non-significant reduction in PTBs was found in the treatment group compared with controls (RR $0.87,95 \%$ CI: 0.69 to 1.08$)^{79}$. There is clearly room for improvement.

Employing a more expansive strategy, the Western Australian PTB Prevention Initiative (WA-PTBPI) was recently established with the intention of safely lowering the rates of PTB in an entire state over a 5-year period 22 . The initiative (badged "thewholeninemonths") is a multidisciplinary, multidimensional approach consisting of an outreach/educational program, a cervical length screening program, a public health/social media program, and a high-risk clinic located at the State's obstetric tertiary referral centre ${ }^{80}$. The key interventions are outlined in Table $1^{80}$. A recent analysis of the effectiveness of the initiative after the first 18 months of operation

\section{Table 1. Key interventions of the Western Australian Preterm Birth Prevention Initiative*}

1. Measurement of cervix length will be conducted routinely at 18-20 weeks' gestation. In those cases in which the cervix can be imaged clearly on a transabdominal scan, a closed length from internal to external os of $\geq 35 \mathrm{~mm}$ is adequate. In all other cases, transvaginal scanning with an empty bladder is required at which a closed cervix length measured by this route of $\leq 25 \mathrm{~mm}$ is considered shortened.

2. Natural vaginal progesterone $200 \mathrm{mg}$ pessary should be administered nightly for any case in which the cervix has been found on ultrasound imaging to be shortened between 16 and 24 weeks' gestation. Treatment is to continue until 36 weeks' gestation. In cases in which the cervix length is $<10 \mathrm{~mm}$ on transvaginal imaging, management can include cervical cerclage, vaginal progesterone, or both.

3. Natural vaginal progesterone $200 \mathrm{mg}$ pessaries for all cases in which there is a history of spontaneous preterm birth (with or without preterm pre-labour rupture of membranes) between 20 and 34 weeks' gestation are to be used each night from 16 to 36 weeks' gestation.

4. No pregnancy is to be ended prior to $\geq 38$ weeks' gestation unless there is a medical or obstetric justification.

5. Women who smoke should be identified and offered counselling though one of the well-established Quitline services offered through the Western Australian Department of Health.

6. A new dedicated and multidisciplinary preterm birth prevention clinic will be established at the tertiary-level centre for referral of highrisk cases. Typically, a management plan is developed and the woman is referred back to her referring practitioner when the high-risk period is concluded. Maternal-fetal medicine specialists, ultrasound imaging facilities for cervix length measurement, and mental health care and midwifery services are available within the clinic.

*Adapted from Newnham et al. ${ }^{80}$ 
revealed a reduction in overall PTB (in singleton pregnancies) in the state by around $8 \%$ compared to pre-intervention rates (from 7.5 to $6.9 \%)^{80}$. This reflects a state-wide reduction of approximately 200 preterm births, including more than 40 in the $<32$-week gestational age group. The rate of late PTB appeared to have decreased rapidly after the commencement of the initiative, suggesting an effect of educational programs aiming to discourage practitioners and women from unnecessary early intervention. The 28-31-week category had a more belated reduction, possibly reflecting benefits from the use of cervix length screening and vaginal progesterone administration $^{80}$.

\section{Treatment and prevention of ascending intrauterine} infection-related preterm birth

Ascending intrauterine infection is the major cause of early PTB and an important preventable cause for all PTBs ${ }^{1,81,82}$. Preterm deliveries driven by infection are more likely to be associated with a) severe chorioamnionitis and funisitis, b) unresponsiveness to tocolysis, c) fetal inflammatory response syndrome (FIRS), and d) poorer neonatal outcomes ${ }^{1,83-85}$. Some of the bacteria that regularly cause infection-driven PTB are common bacteria frequently found in the reproductive tract of pregnant women, but some are found in cases of abnormal vaginal microbiota (e.g. bacterial vaginosis $[\mathrm{BV}])$ and/or are associated with reproductive tract infections ${ }^{86-88}$.

Ureaplasma spp. are the most common microorganisms isolated from the fetal membranes and amniotic cavity of cases of sPTB $^{84,85,89-91}$. Vaginal colonisation rates of Ureaplasma spp. in pregnant women range from 35-90\% $\%^{92}$. Overwhelming evidence shows a clear link between Ureaplasma spp. colonisation, a vigorous inflammatory response, preterm delivery, and adverse neonatal outcomes ${ }^{93-97}$. Two species of Ureaplasma are known to colonise the human vagina, Ureaplasma parvum and Ureaplasma urealyticum $^{92}$. We recently reported that $40 \%$ of pregnant women are colonised with $U$. parvum, while only $11 \%$ were positive for U. urealyticum $^{98}$. Importantly, U. parvum was detected in $77 \%$ of women who went on to have a SPTB compared to $36 \%$ in those who delivered at term. Even more significantly, U. parvum genotype SV6 was 3.6-fold more common in preterm deliveries than those at term, being detected in $54 \%$ of all $\mathrm{sPTBs}^{98}$.

The identification of women at risk of an infection-related preterm delivery is far from simple and to date has relied predominantly on the diagnosis of $\mathrm{BV}$ for the recruitment of women to trials of prophylactic antibiotic administration for PTB prevention. However, $\mathrm{BV}$ is a less-than-optimal diagnostic criterion for risk prediction and trial inclusion. BV has been shown to be predictive of increased risk of PTB in populations with African ethnicities but is a relatively weak risk predictor in Caucasian populations $(\mathrm{OR}<2)^{99-102}$ with a low prevalence rate $(<10 \%)^{99}$. The diagnosis of BV fails to identify many women with vaginal dysbiosis who do not have BV symptoms but who may also be at high risk of infection-associated PTB. Most importantly, BV diagnosis does not take into account Ureaplasma spp. colonisation status or allow the classification of Ureaplasma-positive women to either high or low risk. A diagnostic test based on the presence of U. parvum SV6 and other bacteria is currently under development in our laboratory; in preliminary studies, it considerably outperforms BV as a risk marker and, moreover, identifies women who would benefit from antibiotic therapy and eradication of $U$. parvum infection.

Although several meta-analyses have concluded that antibiotic treatment of BV does not prevent PTB or improve neonatal outcomes ${ }^{103,104}$, a meta-analysis of trials of clindamycin treatment of women with BV prior to 22 weeks' gestation showed a significant reduction in PTB at $\leq 37$ weeks' gestation plus a reduction in the incidence of late miscarriage ${ }^{105}$. We have shown that Ureaplasma spp. colonisation of amniotic fluid occurs primarily after 20 weeks of pregnancy ${ }^{106}$. Importantly, the antibiotics commonly used to treat BV (e.g. clindamycin) show poor activity against Ureaplasma spp., with evidence of significant and growing antibiotic resistance ${ }^{107-109}$. We have recently demonstrated the superiority of a new antibiotic called solithromycin, a fourth-generation macrolide developed to overcome macrolide resistance ${ }^{110}$. It is highly potent against Ureaplasma and Mycoplasma species $^{111}$ plus is effective against all of the bacteria known to cause intra-amniotic infection. Furthermore, it is capable of crossing the placenta and treating the fetus ${ }^{110}$. Solithromycin has not yet been approved for sale, however, and its safety has to be tested before its antenatal applications can be evaluated in clinical trials.

Conventional treatment of BV results in relatively high recurrence and relapse rates ${ }^{112-114}$. Probiotics (both vaginal and oral) have been shown to enhance the effectiveness of treatment of BV and candidiasis and markedly lower rates of recurrence ${ }^{113}$. Probiotics are able to restore microbial homeostasis and exclude colonisation by pathogens ${ }^{12,115}$. It is likely, therefore, that probiotics administered after antibiotic therapy are likely to enhance treatment efficacy and reduce PTB rates; data from large randomised controlled trials to support this expectation are needed.

There is convincing evidence that screening for vaginal infections followed by antimicrobial treatment can significantly reduce the rates of PTB and improve perinatal outcomes. Kiss et al. recruited over 4,400 women in Vienna with singleton pregnancies $\leq 20$ weeks of gestation ${ }^{116}$. Women were screened for BV and presence of Candida spp. and if positive received antimicrobial treatment (clindamycin or clotrimazole as appropriate for six days), repeated if necessary after re-screening at 24-27 weeks. Treatment resulted in significant reductions in $\mathrm{SPTB}$ at $\leq 37$ weeks (43\% reduction) and miscarriage (64\% reduction). In women who screened positive, the overall sPTB rate dropped from 7.0 to $2.9 \%$ with treatment; in women with BV, the PTB rate decreased by $38 \%$ (5.5 to $3.3 \%$ ) and in women with Candida spp. it dropped by $66 \%(7.7 \text { to } 2.6 \%)^{116}$. The magnitude of the effects observed is remarkable compared to the results of other interventions, particularly bearing in mind the poor risk prediction performance of the screening test (RR 1.3). The program was highly cost-effective ${ }^{117}$, with estimated costs amounting to only $7 \%$ of the direct costs saved as a result of the reductions in prematurity (cost:benefit ratio 1:14). As a result of the success of this study, a voluntary antenatal infection "screen and treat" program was introduced in Vienna, offered to women with high risk of PTB due to obstetric risk factors. Recurrent infections were retreated and women were given probiotics after treatment to prevent BV recurrence ${ }^{118,119}$. Remarkably, the results actually exceeded the benefits of the original trial, proving that the 
benefits could be achieved in a routine clinical setting. Increased obstetric care and reassurance to clinic patients may have been a significant contributor to improved outcomes, independent of any direct interventions.

\section{Inflammation-associated preterm birth}

Intra-amniotic infection and inflammation are key drivers of PTB and neonatal morbidity, particularly in infants delivered at $\leq 34$ weeks' gestation $^{1,17}$. Several strategies have been explored to mitigate the effects of inflammation in the neonate ${ }^{120}$; however, few interventions have been developed and evaluated for use prior to delivery, when the greatest therapeutic benefits exist ${ }^{17,121}$.

By conservative estimates, around $40 \%$ of all PTBs are caused by sterile or infection-related IUI, with rates ranging from $\sim 90 \%$ of births at 21-24 weeks' gestation to $\sim 10 \%$ of deliveries at term ${ }^{1,84}$. IUI is commonly associated with PPROM, chorioamnionitis, and funisitis $^{84}$. Severe IUI is associated with FIRS as well as maternal, fetal, and newborn sepsis ${ }^{84}$. In addition to maternal morbidity, IUI increases the risk of major fetal and newborn morbidity ${ }^{1}$. Fetal inflammation leads to haematologic, endocrine, cardiac, renal, immune, and pulmonary abnormalities plus damage to the central nervous system, thymus, gut, and skin, with increased risk of developmental/behavioural abnormalities ${ }^{122,123}$.

The immature fetus may be exposed to inflammation as a result of microbial-driven chorioamnionitis, transplacental viral exposure, or sterile inflammatory insults such as danger-associated molecular patterns (DAMPs), oxidative stress and reactive oxygen species, maternal allograft rejection, uterine distension, senescence, or ischemia/hypoxia ${ }^{17,84}$. Antibiotics may be effective in eradicating infections but cannot treat sterile inflammation ${ }^{124}$. To improve neonatal outcomes, anti-inflammatory interventions are needed to complement antibiotic therapy ${ }^{121}$

A variety of anti-inflammatory pharmacological approaches have been explored to protect against the adverse effects of inflammation in pregnancy ${ }^{120,124,125}$. The therapeutic strategies include a) longterm prophylactic administration to limit excessive inflammation in at-risk women and b) acute administration to women in preterm labour to mitigate the effects of inflammation on the fetus. Pharmacological considerations for these two scenarios are different.

A series of studies exploring the use of cytokine-suppressive antiinflammatory drugs (CSAIDs) have shown pharmacological efficacy in animal and human ex vivo models ${ }^{124}$, demonstrating the ability to block inflammation in human preterm fetal membranes delivered following spontaneous preterm labour ${ }^{126}$ and LPS-driven inflammation in a sheep model via intra-amniotic injection ${ }^{125}$. The effects of these drugs on fetal inflammation following maternal administration have not yet been evaluated, however, and their use in the clinic is still some way off.

The compound (+)-naloxone is a potent TLR4 signalling antagonist and a non-opioid isomer of the widely used opioid receptor antagonist (-)-naloxone ${ }^{127}$. (+)-naloxone suppresses immune $\mathrm{NF}-\kappa \mathrm{B}$ activation and cytokine biosynthesis ${ }^{128-130}$, protecting against sepsis in animal models ${ }^{131,132}$. (+)-naloxone administered in late gestation delays the timing of birth by 16 hours $^{133}$ and alleviates fetal demise after intraperitoneal LPS administration ${ }^{134}$. In a model of Escherichia coli-induced IUI, (+)-naloxone protected pups from PTB and perinatal death ${ }^{134}$ and suppressed cytokine expression in fetal membranes, placenta, uterine myometrium, and decidua ${ }^{134}$. Importantly, (+)-naloxone had no adverse effects on fetal or neonatal development, and the history of (-)-naloxone use in pregnancy suggests that the drug is safe and without significant risks.

An alternative approach that has been tested is to block the actions of key cytokines such as IL-1, which plays a pivotal role in uterine and placental inflammation and also in mediating the adverse effects of inflammation in the fetal brain and other organs ${ }^{135}$. Studies using the commercially available antagonist Kineret have been overshadowed by a new, allosteric peptide IL-1R antagonist known as rytvela ${ }^{136}$. Rytvela treatment in pregnant mice improved fetal and neonatal outcomes following exposure to either IL-1 $\beta$ or LPS ${ }^{136-138}$, blocked uterine/placental/intra-amniotic inflammation, and prevented myometrial activation, PTB, fetal demise, and inflammation-related morbidities; rytvela-exposed pups exhibited overtly normal growth and development ${ }^{137,138}$. In all studies, rytvela equalled or outperformed Kineret, despite being used at lower doses. This exciting pharmacological advance is undergoing further preclinical evaluation prior to clinical trials.

Statins have also been proposed to have a role in mitigating the negative effects of inflammation in pregnancy ${ }^{139}$. Studies in the LPS mouse model have shown that statin administration prevents cervical remodelling, myometrial contractility, and $\mathrm{PTB}^{140}$ and reduces cytokine expression in the uterus, cervix, serum, and amniotic fluid $^{141}$. Similar effects have been shown in human fetal membranes ${ }^{142}$. Several large prospective studies are underway to confirm reports ${ }^{143,144}$ that statin administration is safe in pregnancy.

\section{Concluding comments}

The PTB prevention landscape has altered significantly in the last decade or so, with the mainstream introduction of dedicated PTB prevention clinics, transvaginal ultrasound cervical length screening programs, and progesterone administration to women at high risk $^{22}$. However, the gains achieved by these initiatives are modest at best, and there is significant scope to improve the effectiveness and targeting of therapies and the accuracy of our risk assessment strategies. To this end, several promising developments that have the potential to significantly lower PTB rates have been described. In going forward, we must be mindful that the primary goal is to improve outcomes for the infant in both the short and the long term. This requires trialists to employ a consistent set of endpoints ${ }^{145-147}$ that include the assessment of a range of neonatal/paediatric respiratory and neurodevelopmental parameters ${ }^{32,34}$.

One also has to be realistic in terms of what can be achieved. No intervention is $100 \%$ effective, and a significant proportion of PTBs are the result of unidentified causes and are completely unpredictable by current methods ${ }^{22}$. Furthermore, as a syndrome, PTB is 
the result of many different aetiologies and as such may require multiple interventions targeted to different subgroups based on risk stratification and prognostic profiling. Nevertheless, as the research reviewed in this article highlights, there are a number of avenues where it appears that significant progress can be made and further advances are highly likely; the opportunities for short-to-medium gains are plentiful.

\section{Competing interests}

The authors declare that they have no competing interests.

\section{Grant information}

The author(s) declared that no grants were involved in supporting this work.

\section{Acknowledgements}

The continued funding support of Women and Infants Research Foundation who have provided general financial support including paying salary and supporting PTB Prevention Initiative, the Channel 7 Telethon Trust who have provided funds for research over many years and the National Health and Medical Research Foundation who have funded several research projects is gratefully acknowledged.
1. Romero R, Dey SK, Fisher SJ: Preterm labor: one syndrome, many causes. Science. 2014; 345(6198): 760-5. PubMed Abstract | Publisher Full Text | Free Full Text

2. Rubens $C E$, Sadovsky $Y$, Muglia L, et al: Prevention of preterm birth: harnessing science to address the global epidemic. Sci Transl Med. 2014; 6(262): 262sr5. PubMed Abstract | Publisher Full Text

3. Lawn JE, Gravett MG, Nunes TM, et al:: Global report on preterm birth and stillbirth (1 of 7): definitions, description of the burden and opportunities to improve data. BMC Pregnancy Childbirth. 2010; 10(Suppl 1): S1. PubMed Abstract | Publisher Full Text | Free Full Text

4. Chang $\mathrm{HH}$, Larson J, Blencowe $\mathrm{H}$, et al:: Preventing preterm births: analysis of trends and potential reductions with interventions in 39 countries with very high human development index. Lancet. 2013; 381(9862): 223-34. PubMed Abstract | Publisher Full Text | Free Full Text

5. Harrison MS, Goldenberg RL: Global burden of prematurity. Semin Fetal Neonatal Med. 2016; 21(2): 74-9.

PubMed Abstract | Publisher Full Tex

6. Beck S, Wojdyla D, Say L, et al:: The worldwide incidence of preterm birth: a systematic review of maternal mortality and morbidity. Bull World Health Organ. 2010; 88(1): 31-8.

PubMed Abstract | Publisher Full Text | Free Full Text

7. Catov JM, Scifres CM, Caritis SN, et al:: Neonatal outcomes following preterm birth classified according to placental features. Am J Obstet Gynecol. 2017; 216(4): 411.e1-411.e14.

PubMed Abstract | Publisher Full Tex

8. Glass HC, Costarino AT, Stayer SA, et al:: Outcomes for extremely premature infants. Anesth Analg. 2015; 120(6): 1337-51. PubMed Abstract | Publisher Full Text | Free Full Text

9. Platt MJ: Outcomes in preterm infants. Public Health. 2014; 128(5): 399-403. PubMed Abstract | Publisher Full Text

10. Brown HK, Speechley KN, Macnab J, et al:: Neonatal morbidity associated with late preterm and early term birth: the roles of gestational age and biological determinants of preterm birth. Int J Epidemiol. 2014; 43(3): 802-14. PubMed Abstract | Publisher Full Text | Free Full Text

11. Shah PS, Lui K, Sjörs G, et al.: Neonatal Outcomes of Very Low Birth Weight and Very Preterm Neonates: An International Comparison. J Pediatr. 2016; 177: 144-152.e6.

PubMed Abstract | Publisher Full Text

12. Strunk $\mathrm{T}$, Inder $\mathrm{T}$, Wang $\mathrm{X}$, et al.: Infection-induced inflammation and cerebral injury in preterm infants. Lancet Infect Dis. 2014; 14(8): 751-62. PubMed Abstract | Publisher Full Text | Free Full Text

13. Weiner $E$, Dekalo A, Feldstein $O$, et al:: The placental factor in spontaneous preterm birth in twin vs. singleton pregnancies. Eur J Obstet Gynecol Reprod Biol. 2017; 214: 1-5.

PubMed Abstract | Publisher Full Tex

14. Stanek J: Comparison of placental pathology in preterm, late-preterm, nearterm, and term births. Am J Obstet Gynecol. 2014; 210(3): 234.e1-6. PubMed Abstract | Publisher Full Text

15. Keelan JA: Intrauterine inflammatory activation, functional progesterone withdrawal, and the timing of term and preterm birth. Journal of Reproductive Immunology. 2017
16. Behnia $F$, Taylor $B D$, Woodson $M$, et al: Chorioamniotic membrane senescence: a signal for parturition? Am J Obstet Gynecol. 2015; 213(3): 359.e1-16. PubMed Abstract | Publisher Full Text

17. Nadeau-Vallée M, Obari D, Palacios J, et al: Sterile inflammation and pregnancy complications: a review. Reproduction. 2016; 152(6): R277-R292. PubMed Abstract | Publisher Full Text

18. F van Vliet EO, Askie LA, Mol BW, et al.: Antiplatelet Agents and the Prevention of Spontaneous Preterm Birth: A Systematic Review and Metaanalysis. Obstet Gynecol. 2017; 129(2): 327-36. PubMed Abstract | Publisher Full Text | F1000 Recommendation

19. F Allshouse AA, Jessel RH, Heyborne KD: The impact of low-dose aspirin on preterm birth: secondary analysis of a randomized controlled trial. $J$ Perinatol. 2016; 36(6): 427-31.

PubMed Abstract | Publisher Full Text | F1000 Recommendation

20. F Silver RM, Ahrens $\mathrm{K}$, Wong LF, et al:: Low-dose aspirin and preterm birth: randomized controlled trial Obstet Gynecol. 2015; 125(4): 876-84. PubMed Abstract | Publisher Full Text | F1000 Recommendation

21. Morgan TK: Role of the Placenta in Preterm Birth: A Review. Am J Perinatol. 2016; 33(3): 258-66.

PubMed Abstract | Publisher Full Text

22. Newnham JP, Dickinson JE, Hart RJ, et al.: Strategies to prevent preterm birth Front Immunol. 2014; 5: 584.

PubMed Abstract | Publisher Full Text | Free Full Text

23. Newnham JP, Kemp MW, White SW, et al:: Applying Precision Public Health to Prevent Preterm Birth. Front Public Health. 2017; 5: 66 PubMed Abstract | Publisher Full Text | Free Full Text

24. Toivonen KI, Oinonen KA, Duchene KM: Preconception health behaviours: $\mathbf{A}$ scoping review. Prev Med. 2017; 96: 1-15. PubMed Abstract | Publisher Full Text

25. F Lengyel CS, Ehrlich S, lams JD, et al:: Effect of Modifiable Risk Factors on Preterm Birth: A Population Based-Cohort. Matern Child Health J. 2017; 21(4): $777-85$

PubMed Abstract | Publisher Full Text | F1000 Recommendation

26. Frayne J, Hauck Y: Enjoying a healthy pregnancy: GPs' essential role in health promotion. Aust Fam Physician. 2017; 46(1): 20-5 PubMed Abstract

27. F Poels M, Koster MP, Boeije HR, et al.: Why Do Women Not Use Preconception Care? A Systematic Review On Barriers And Facilitators. Obstet Gynecol Surv. 2016; 71(10): 603-12. PubMed Abstract | Publisher Full Text | F1000 Recommendation

28. van Zijl MD, Koullali B, Mol BW, et al.: Prevention of preterm delivery: curren challenges and future prospects. Int $J$ Womens Health. 2016; 8: 633-45. PubMed Abstract | Publisher Full Text | Free Full Text

29. F Jarde A, Lutsiv O, Park CK, et al:: Effectiveness of progesterone, cerclage and pessary for preventing preterm birth in singleton pregnancies: a systematic review and network meta-analysis. BJOG. 2017; 124(8): 1176-1189. PubMed Abstract | Publisher Full Text | F1000 Recommendation

30. F Berghella V, Ciardulli A, Rust OA, et al:: Cerclage for Short Cervix on 
Ultrasound in Singleton Gestations without Prior Spontaneous Preterm Birth: a Systematic Review and Meta-analysis of Trials using individual patient-level data. Ultrasound Obstet Gynecol. 2017.

PubMed Abstract | Publisher Full Text | F1000 Recommendation

31. Ahn $\mathrm{KH}$, Bae NY, Hong SC, et al.: The safety of progestogen in the prevention of preterm birth: meta-analysis of neonatal mortality. J Perinat Med. 2017; 45(1): $11-20$.

PubMed Abstract | Publisher Full Text

32. Norman JE, Marlow N, Messow CM, et al: Vaginal progesterone prophylaxis fo preterm birth (the OPPTIMUM study): a multicentre, randomised, double-blind trial. Lancet. 2016; 387(10033): 2106-16.

PubMed Abstract | Publisher Full Text | Free Full Text

33. Chung CM, van Zijl M, Keelan JA, et al.: Progesterone to prevent preterm birth: the studies are getting better, but there is still room for improvement. BJOG. 2017; 124(7): 1016.

PubMed Abstract | Publisher Full Text

34. Romero R, Nicolaides $\mathrm{KH}$, Conde-Agudelo $\mathrm{A}$, et al.: Vaginal progesterone decreases preterm birth $\leq \mathbf{3 4}$ weeks of gestation in women with a singleton pregnancy and a short cervix: an updated meta-analysis including data from the OPPTIMUM study. Ultrasound Obstet Gynecol. 2016; 48(3): 308-17. PubMed Abstract | Publisher Full Text | Free Full Text

35. Wagner CK: Progesterone receptors and neural development: a gap between bench and bedside? Endocrinology. 2008; 149(6): 2743-9. PubMed Abstract | Publisher Full Text | Free Full Text

36. Willing J, Wagner CK: Exposure to the Synthetic Progestin, 17a-Hydroxyprogesterone Caproate During Development Impairs Cognitive Flexibility in Adulthood. Endocrinology. 2016; 157(1): 77-82.

PubMed Abstract | Publisher Full Text | Free Full Text

37. Saccone G, Khalifeh A, Elimian A, et al:: Vaginal progesterone vs intramuscular 17 $\alpha$-hydroxyprogesterone caproate for prevention of recurrent spontaneous preterm birth in singleton gestations: systematic review and meta-analysis of randomized controlled trials. Ultrasound Obstet Gynecol. 2017; 49(3): 315-21. PubMed Abstract | Publisher Full Text

38. Pirjani R, Heidari R, Rahimi-Foroushani A, et al:: 17-alpha-hydroxyprogesterone caproate versus vaginal progesterone suppository for the prevention of preterm birth in women with a sonographically short cervix: A randomized controlled trial. J Obstet Gynaecol Res. 2017: 43(1): 57-64. PubMed Abstract | Publisher Full Text

39. F Fox NS, Gupta S, Lam-Rachlin J, et al:: Cervical Pessary and Vaginal Progesterone in Twin Pregnancies With a Short Cervix. Obstet Gynecol. 2016; 127(4): 625-30.

PubMed Abstract | Publisher Full Text | F1000 Recommendation

40. Combs CA, Garite TJ, Maurel K, et al: Fetal fibronectin versus cervical length as predictors of preterm birth in twin pregnancy with or without 17-hydroxyprogesterone caproate. Am J Perinatol. 2014; 31(12): 1023-30. PubMed Abstract | Publisher Full Text

41. Jarde A, Lutsiv O, Park CK, et al: Preterm birth prevention in twin pregnancies with progesterone, pessary, or cerclage: a systematic review and metaanalysis. BJOG. 2017; 124(8): 1163-1173. PubMed Abstract | Publisher Full Text

42. F Romero R, Conde-Agudelo A, El-Refaie W, et al:: Vaginal progesterone decreases preterm birth and neonatal morbidity and mortality in women with a twin gestation and a short cervix: an updated meta-analysis of individual patient data. Ultrasound Obstet Gynecol. 2017; 49(3): 303-14. PubMed Abstract | Publisher Full Text | Free Full Text | F1000 Recommendation

43. F Nelson DB, McIntire DD, McDonald J, et al.: 17-alpha Hydroxyprogesterone caproate did not reduce the rate of recurrent preterm birth in a prospective cohort study. Am J Obstet Gynecol. 2017; 216(6): 600.e1-600.e9. PubMed Abstract | Publisher Full Text | Free Full Text | F1000 Recommendation

44. F Manuck TA, Stoddard GJ, Fry RC, et al:: Nonresponse to 17-alpha hydroxyprogesterone caproate for recurrent spontaneous preterm birth prevention: clinical prediction and generation of a risk scoring system. Am J Obstet Gynecol. 2016; 215(5): 622.e1-622.e8.

PubMed Abstract | Publisher Full Text | Free Full Text | F1000 Recommendation

45. F Furcron AE, Romero R, Plazyo O, et al:: Vaginal progesterone, but not 17a-hydroxyprogesterone caproate, has antiinflammatory effects at the murine maternal-fetal interface. Am J Obstet Gynecol. 2015; 213(6): 846.e1-846.e19. PubMed Abstract | Publisher Full Text | Free Full Text | F1000 Recommendation

46. Romero R, Stanczyk FZ: Progesterone is not the same as $17 \alpha-$ hydroxyprogesterone caproate: implications for obstetrical practice. Am J Obstet Gynecol. 2013; 208(6): 421-6. PubMed Abstract | Publisher Full Text | Free Full Text

47. $\mathrm{F}$ Elimian $\mathrm{A}$, Smith $\mathrm{K}$, Williams $\mathrm{M}$, et al.: A randomized controlled trial of intramuscular versus vaginal progesterone for the prevention of recurren preterm birth. Int J Gynaecol Obstet. 2016; 134(2): 169-72. PubMed Abstract | Publisher Full Text | F1000 Recommendation

48. Maerdan M, Shi C, Zhang X, et al:: The prevalence of short cervix between 20 and 24 weeks of gestation and vaginal progesterone for prolonging of gestation. J Matern Fetal Neonatal Med. 2017; 30(14): 1646-9.

PubMed Abstract | Publisher Full Text

49. Pedretti MK, Kazemier BM, Dickinson JE, et al.: Implementing universal cervical length screening in asymptomatic women with singleton pregnancies: challenges and opportunities. Aust N Z J Obstet Gynaecol. 2017; 57(2): 221-7. PubMed Abstract | Publisher Full Text

50. F Temming LA, Durst JK, Tuuli MG, et al.: Universal cervical length screening: implementation and outcomes. Am J Obstet Gynecol. 2016; 214(4): 523.e1-8. PubMed Abstract | Publisher Full Text | Free Full Text | F1000 Recommendation

51. F Orzechowski KM, Boelig R, Nicholas SS, et al:: Is universal cervical length screening indicated in women with prior term birth? Am J Obstet Gynecol. 2015; 212(2): 234.e1-5

PubMed Abstract | Publisher Full Text | F1000 Recommendation

52. F Einerson BD, Grobman WA, Miller ES: Cost-effectiveness of risk-based screening for cervical length to prevent preterm birth. Am J Obstet Gynecol. 2016; 215(1): 100.e1-7.

PubMed Abstract | Publisher Full Text | F1000 Recommendation

53. Miller ES, Grobman WA: Cost-effectiveness of transabdominal ultrasound for cervical length screening for preterm birth prevention. Am J Obstet Gynecol. 2013; 209(6): 546.e1-6.

PubMed Abstract | Publisher Full Text

54. F Werner EF, Hamel MS, Orzechowski K, et al:: Cost-effectiveness of transvaginal ultrasound cervical length screening in singletons without a prio preterm birth: an update. Am J Obstet Gynecol. 2015; 213(4): 554.e1-6. PubMed Abstract | Publisher Full Text | F1000 Recommendation

55. Jain S, Kilgore M, Edwards RK, et al.: Revisiting the cost-effectiveness of universal cervical length screening: importance of progesterone efficacy. $A m J$ Obstet Gynecol. 2016; 215(1): 101.e1-7. PubMed Abstract | Publisher Full Text

56. F Koucký M, Malíčková K, Cindrová-Davies T, et al:: Prolonged progesterone administration is associated with less frequent cervicovaginal colonization by Ureaplasma urealyticum during pregnancy - Results of a pilot study. J Reprod Immunol. 2016; 116: 35-41.

PubMed Abstract | Publisher Full Text | F1000 Recommendation

57. F Kiefer DG, Peltier MR, Keeler SM, et al:: Efficacy of midtrimester short cervix interventions is conditional on intraamniotic inflammation. Am J Obstet Gynecol. 2016; 214(2): 276.e1-6.

PubMed Abstract | Publisher Full Text | F1000 Recommendation

58. F Rajagopal SP, Hutchinson JL, Dorward DA, et al:: Crosstalk between monocytes and myometrial smooth muscle in culture generates synergistic pro-inflammatory cytokine production and enhances myocyte contraction, with effects opposed by progesterone. Mol Hum Reprod. 2015; 21(8): 672-86. PubMed Abstract | Publisher Full Text | Free Full Text | F1000 Recommendation

59. Georgiou HM, Di Quinzio MK, Permezel M, et al:: Predicting Preterm Labour: Current Status and Future Prospects. Dis Markers. 2015; 2015: 435014. PubMed Abstract | Publisher Full Text | Free Full Text

60. F Hadži-Legal M, Markova AD, Stefanovic M, et al:: Combination of selected biochemical markers and cervical length in the prediction of impending preterm delivery in symptomatic patients. Clin Exp Obstet Gynecol. 2016; 43(1): $154-60$

PubMed Abstract | Publisher Full Text | F1000 Recommendation

61. Saade GR, Boggess KA, Sullivan SA, et al:: Development and validation of a spontaneous preterm delivery predictor in asymptomatic women. Am J Obstet Gynecol. 2016; 214(5): 633.e1-633.e24. PubMed Abstract | Publisher Full Text

62. F Heng YJ, Pennell CE, McDonald SW, et al:: Maternal Whole Blood Gene Expression at 18 and 28 Weeks of Gestation Associated with Spontaneous Preterm Birth in Asymptomatic Women. PLoS One. 2016; 11(6): e0155191. PubMed Abstract | Publisher Full Text | Free Full Text | F1000 Recommendation

63. Heng YJ, Pennell CE, Chua HN, et al:: Whole blood gene expression profile associated with spontaneous preterm birth in women with threatened preterm labor. PLoS One. 2014; 9(5): e96901.

PubMed Abstract | Publisher Full Text | Free Full Text

64. F Gunko VO, Pogorelova TN, Linde VA: Proteomic Profiling of the Blood Serum for Prediction of Premature Delivery. Bull Exp Biol Med. 2016; 161(6): 829-32. PubMed Abstract | Publisher Full Text | F1000 Recommendation

65. Andersen HF, Nugent CE, Wanty SD, et al:: Prediction of risk for preterm delivery by ultrasonographic measurement of cervical length. Am J Obstet Gynecol. 1990; 163(3): 859-67. PubMed Abstract | Publisher Full Text

66. lams JD, Goldenberg RL, Meis PJ, et al.: The length of the cervix and the risk of spontaneous premature delivery. National Institute of Child Health and Human Development Maternal Fetal Medicine Unit Network. N Engl J Med. 1996; 334(9): $567-72$

PubMed Abstract | Publisher Full Text

67. Hassan SS, Romero R, Berry SM, et al:: Patients with an ultrasonographic cervical length $<$ or $=15 \mathrm{~mm}$ have nearly a $50 \%$ risk of early spontaneous preterm delivery. Am J Obstet Gynecol. 2000; 182(6): 1458-67. PubMed Abstract | Publisher Full Text

68. F Markham KB, lams JD: Measuring the Cervical Length. Clin Obstet Gynecol. 2016; 59(2): 252-63. PubMed Abstract | Publisher Full Text | F1000 Recommendation

69. F Bohîlțea RE, Munteanu O, Turcan N, et al.: A debate about ultrasound and anatomic aspects of the cervix in spontaneous preterm birth. $J$ Med Life. 
2016; 9(4): 342-7.

PubMed Abstract | Free Full Text | F1000 Recommendation

70. Rozenberg P: Universal cervical length screening for singleton pregnancies with no history of preterm delivery, or the inverse of the Pareto principle. BJOG. 2017; 124(7): 1038-45. PubMed Abstract | Publisher Full Text

71. Son M, Grobman WA, Ayala NK, et al.: A universal mid-trimester transvaginal cervical length screening program and its associated reduced preterm birth rate. Am J Obstet Gynecol. 2016; 214(3): 365.e1-5.

PubMed Abstract | Publisher Full Text

72. Dziadosz M, Bennett T, Dolin C, et al.: Uterocervical angle: a novel ultrasound screening tool to predict spontaneous preterm birth. Am J Obstet Gynecol. 2016; 215(3): 376.e1-7.

PubMed Abstract | Publisher Full Text

73. Fruscalzo A, Mazza E, Feltovich $\mathrm{H}$, et al:: Cervical elastography during pregnancy: a critical review of current approaches with a focus on controversies and limitations. J Med Ultrason (2001). 2016; 43(3): 493-504. PubMed Abstract | Publisher Full Text

74. $\operatorname{Kim~H}$, Hwang HS: Elastographic measurement of the cervix during pregnancy: Current status and future challenges. Obstet Gynecol Sci. 2017; 60(1): 1-7. PubMed Abstract | Publisher Full Text | Free Full Text

75. F Oturina V, Hammer K, Möllers M, et al.: Assessment of cervical elastography strain pattern and its association with preterm birth. $J$ Perinat Med. 2017; pii: /j/jpme.ahead-of-print/jpm-2016-0375/jpm-2016-0375.xml. PubMed Abstract | F1000 Recommendation

76. Hobel CJ, Ross MG, Bemis RL, et al:: The West Los Angeles Preterm Birth Prevention Project. I. Program impact on high-risk women. Am J Obstet Gynecol. 1994; 170(1 Pt 1): 54-62. PubMed Abstract | Publisher Full Text

77. Manuck TA, Henry E, Gibson J, et al.: Pregnancy outcomes in a recurrent preterm birth prevention clinic. Am J Obstet Gynecol. 2011; 204(4): 320.e1-6. PubMed Abstract | Publisher Full Text

78. Sharp AN, Alfirevic Z: Provision and practice of specialist preterm labour clinics: a UK survey of practice. BJOG. 2014; 121(4): 417-21.

PubMed Abstract | Publisher Full Text

79. Whitworth M, Quenby S, Cockerill RO, et al.: Specialised antenatal clinics for women with a pregnancy at high risk of preterm birth (excluding multiple pregnancy) to improve maternal and infant outcomes. Cochrane Database Syst Rev. 2011; (9): CD006760.

PubMed Abstract | Publisher Full Text | Free Full Text

80. Newnham JP, White SW, Meharry S, et al:: Reducing preterm birth by a statewide multifaceted program: an implementation study. Am J Obstet Gynecol. 2017; 216(5): 434-42.

PubMed Abstract | Publisher Full Text

81. Kim CJ, Romero R, Chaemsaithong $\mathrm{P}$, et al:: Chronic inflammation of the placenta: definition, classification, pathogenesis, and clinical significance. $A m$ J Obstet Gynecol. 2015; 213(4 Suppl): S53-69.

PubMed Abstract | Publisher Full Text | Free Full Text

82. Kemp MW: Preterm birth, intrauterine infection, and fetal inflammation. Front Immunol. 2014; 5: 574.

PubMed Abstract | Publisher Full Text | Free Full Text

83. Romero R, Miranda J, Chaiworapongsa $T$, et al: Prevalence and clinical significance of sterile intra-amniotic inflammation in patients with preterm labor and intact membranes. Am J Reprod Immunol. 2014; 72(5): 458-74. PubMed Abstract | Publisher Full Text | Free Full Text

84. Kim CJ, Romero R, Chaemsaithong $\mathrm{P}$, et al: Acute chorioamnionitis and funisitis: definition, pathologic features, and clinical significance. Am J Obstet Gynecol. 2015; 213(4 Suppl): S29-52. PubMed Abstract | Publisher Full Text | Free Full Text

85. F Cobo T, Vives I, Rodríguez-Trujillo A, et al.: Impact of microbial invasion of amniotic cavity and the type of microorganisms on short-term neonatal outcome in women with preterm labor and intact membranes. Acta Obstet Gynecol Scand. 2017; 96(5): 570-9.

PubMed Abstract | Publisher Full Text | F1000 Recommendation

86. DiGiulio DB: Diversity of microbes in amniotic fluid. Semin Fetal Neonatal Med. 2012; 17(1): 2-11.

PubMed Abstract | Publisher Full Text

87. Donders GG, Larsson PG, Platz-Christensen JJ, et al.: Variability in diagnosis of clue cells, lactobacillary grading and white blood cells in vaginal wet smears with conventional bright light and phase contrast microscopy. Eur J Obstet Gynecol Reprod Biol. 2009; 145(1): 109-12.

PubMed Abstract | Publisher Full Text

88. Mendz GL, Kaakoush NO, Quinlivan JA: Bacterial aetiological agents of intraamniotic infections and preterm birth in pregnant women. Front Cell Infect Microbiol. 2013; 3: 58.

PubMed Abstract | Publisher Full Text | Free Full Text

89. Sweeney EL, Kallapur SG, Gisslen T, et al.: Placental Infection With Ureaplasma species Is Associated With Histologic Chorioamnionitis and Adverse Outcomes in Moderately Preterm and Late-Preterm Infants. J Infect Dis. 2016; 213(8): 1340-7.

PubMed Abstract | Publisher Full Text | Free Full Text

90. Combs CA, Gravett M, Garite TJ, et al:: Amniotic fluid infection, inflammation, and colonization in preterm labor with intact membranes. Am J Obstet Gynecol.
2014; 210(2): 125.e1-125.e15

PubMed Abstract | Publisher Full Text

91. Viscardi RM: Ureaplasma species: role in neonatal morbidities and outcomes. Arch Dis Child Fetal Neonatal Ed. 2014; 99(1): F87-92. PubMed Abstract | Publisher Full Text | Free Full Text

92. Capoccia R, Greub G, Baud D: Ureaplasma urealyticum, Mycoplasma hominis and adverse pregnancy outcomes. Curr Opin Infect Dis. 2013; 26(3): 231-40. PubMed Abstract | Publisher Full Text

93. Murtha AP, Edwards JM: The role of Mycoplasma and Ureaplasma in adverse pregnancy outcomes. Obstet Gynecol Clin North Am. 2014; 41(4): 615-27. PubMed Abstract | Publisher Full Text

94. Kasper DC, Mechtler TP, Reischer GH, et al.: The bacterial load of Ureaplasma parvum in amniotic fluid is correlated with an increased intrauterine inflammatory response. Diagn Microbiol Infect Dis. 2010; 67(2): 117-21. PubMed Abstract | Publisher Full Text

95. Kirchner L, Helmer H, Heinze G, et al:: Amnionitis with Ureaplasma urealyticum or other microbes leads to increased morbidity and prolonged hospitalization in very low birth weight infants. Eur J Obstet Gynecol Reprod Biol. 2007; 134(1): 44-50.

PubMed Abstract | Publisher Full Text

96. Oh KJ, Lee KA, Sohn YK, et al.: Intraamniotic infection with genital mycoplasmas exhibits a more intense inflammatory response than intraamniotic infection with other microorganisms in patients with preterm premature rupture of membranes. Am J Obstet Gynecol. 2010; 203(3): 211.e1-8. PubMed Abstract | Publisher Full Text

97. Yoon BH, Romero R, Park JS, et al.: Microbial invasion of the amniotic cavity with Ureaplasma urealyticum is associated with a robust host response in fetal, amniotic, and maternal compartments. Am J Obstet Gynecol. 1998; 179(5): 1254-60.

PubMed Abstract | Publisher Full Text

98. Payne MS, Ireland DJ, Watts R, et al.: Ureaplasma parvum genotype, combined vaginal colonisation with Candida albicans, and spontaneous preterm birth in an Australian cohort of pregnant women. BMC Pregnancy Childbirth. 2016; 16(1): 312.

PubMed Abstract | Publisher Full Text | Free Full Text

99. $\mathrm{F}$ Donders GG, Van Calsteren K, Bellen G, et al.: Predictive value for preterm birth of abnormal vaginal flora, bacterial vaginosis and aerobic vaginitis during the first trimester of pregnancy. BJOG. 2009; 116(10): 1315-24. PubMed Abstract | Publisher Full Text | F1000 Recommendation

100. Kekki M, Kurki T, Kotomäki T, et al:: Cost-effectiveness of screening and treatment for bacterial vaginosis in early pregnancy among women at low risk for preterm birth. Acta Obstet Gynecol Scand. 2004; 83(1): 27-36. PubMed Abstract | Publisher Full Text

101. Leitich $\mathrm{H}$, Bodner-Adler $\mathrm{B}$, Brunbauer $\mathrm{M}$, et al.: Bacterial vaginosis as a risk factor for preterm delivery: a meta-analysis. Am J Obstet Gynecol. 2003; 189(1): $139-47$.

PubMed Abstract | Publisher Full Text

102. Foxman B, Wen A, Srinivasan U, et al:: Mycoplasma, bacterial vaginosisassociated bacteria BVAB3, race, and risk of preterm birth in a high-risk cohort. Am J Obstet Gynecol. 2014: 210(3): 226.e1-7. PubMed Abstract | Publisher Full Text | Free Full Text

103. Morency AM, Bujold E: The effect of second-trimester antibiotic therapy on the rate of preterm birth. J Obstet Gynaecol Can. 2007; 29(1): 35-44. PubMed Abstract | Publisher Full Text

104. Lamont RF, Keelan JA, Larsson PG, et al:: The treatment of bacterial vaginosis in pregnancy with clindamycin to reduce the risk of infection-related preterm birth: a response to the Danish Society of Obstetrics and Gynecology guideline group's clinical recommendations. Acta Obstet Gynecol Scand. 2017; 96(2): 139-43. PubMed Abstract | Publisher Full Text

105. F Lamont RF: Advances in the Prevention of Infection-Related Preterm Birth Front Immunol. 2015; 6: 566

PubMed Abstract | Publisher Full Text | Free Full Text | F1000 Recommendation

106. Payne MS, Feng Z, Li S, et al.: Second trimester amniotic fluid cytokine concentrations, Ureaplasma sp. colonisation status and sexual activity as predictors of preterm birth in Chinese and Australian women. BMC Pregnancy Childbirth. 2014; 14: 340 PubMed Abstract | Publisher Full Text | Free Full Text

107. F Gomez R, Romero R, Nien JK, et al:: Antibiotic administration to patients with preterm premature rupture of membranes does not eradicate intraamniotic infection. J Matern Fetal Neonatal Med. 2007; 20(2): 167-73. PubMed Abstract | Publisher Full Text | F1000 Recommendation

108. Krausse R, Schubert S: In-vitro activities of tetracyclines, macrolides, fluoroquinolones and clindamycin against Mycoplasma hominis and Ureaplasma ssp. isolated in Germany over 20 years. Clin Microbiol Infect. 2010; 16(11): 1649-55

PubMed Abstract | Publisher Full Text

109. Redelinghuys MJ, Ehlers MM, Dreyer AW, et al.: Antimicrobial susceptibility patterns of Ureaplasma species and Mycoplasma hominis in pregnant women. BMC Infect Dis. 2014; 14: 171. PubMed Abstract | Publisher Full Text | Free Full Text

110. Keelan JA, Payne MS, Kemp MW, et al: A New, Potent, and Placenta-Permeable Macrolide Antibiotic, Solithromycin, for the Prevention and Treatment of 
Bacterial Infections in Pregnancy. Front Immunol. 2016; 7: 111. PubMed Abstract | Publisher Full Text | Free Full Text

111. Furfaro LL, Spiller OB, Keelan JA, et al.: In vitro activity of solithromycin and its metabolites, CEM-214 and $\mathrm{N}$-acetyl-CEM-101, against 100 clinical Ureaplasma spp. isolates compared with azithromycin. Int J Antimicrob Agents. 2015; 46(3): 319-24.

PubMed Abstract | Publisher Full Text

112. Donders GG, Zodzika J, Rezeberga D: Treatment of bacterial vaginosis: what we have and what we miss. Expert Opin Pharmacother. 2014; 15(5): 645-57. PubMed Abstract | Publisher Full Text

113. Parma M, Stella Vanni V, Bertini M, et al.: Probiotics in the prevention of recurrences of bacterial vaginosis. Altern Ther Health Med. 2014; 20(Suppl 1): 52-7. PubMed Abstract

114. van Schalkwyk J, Yudin MH; INFECTIOUS DISEASE COMMITTEE: Vulvovaginitis: screening for and management of trichomoniasis, vulvovaginal candidiasis, and bacterial vaginosis. J Obstet Gynaecol Can. 2015; 37(3): 266-74. PubMed Abstract | Publisher Full Text

115. Griffin C: Probiotics in obstetrics and gynaecology. Aust N Z J Obstet Gynaecol. 2015; 55(3): 201-9. PubMed Abstract | Publisher Full Text

116. Kiss $\mathrm{H}$, Petricevic L, Husslein P: Prospective randomised controlled trial of an infection screening programme to reduce the rate of preterm delivery. BMJ. 2004; 329(7462): 371 PubMed Abstract | Publisher Full Text | Free Full Text

117. Kiss $\mathrm{H}$, Pichler E, Petricevic L, et al:: Cost effectiveness of a screen-and-treat program for asymptomatic vaginal infections in pregnancy: towards a significant reduction in the costs of prematurity. Eur J Obstet Gynecol Reprod Biol. 2006; 127(2): 198-203.

PubMed Abstract | Publisher Full Text

118. F Farr A, Kiss $\mathrm{H}$, Hagmann $\mathrm{M}$, et al:: Routine use of an antenatal infection screen-and-treat program to prevent preterm birth: long-term experience at a tertiary referral center. Birth. 2015; 42(2): 173-80. PubMed Abstract | Publisher Full Text | F1000 Recommendation

119. Kiss H, Petricevic L, Martina S, et al:: Reducing the rate of preterm birth through a simple antenatal screen-and-treat programme: a retrospective cohort study. Eur J Obstet Gynecol Reprod Biol. 2010; 153(1): 38-42. PubMed Abstract | Publisher Full Text

120. Keelan JA: Pharmacological inhibition of inflammatory pathways for the prevention of preterm birth. J Reprod Immunol. 2011; 88(2): 176-84. PubMed Abstract | Publisher Full Text

121. Taguchi A, Yamashita A, Kawana K, et al:: Recent progress in Therapeutics for Inflammation-Associated Preterm Birth: A review. Reprod Sci. 2015; pi 1933719115618282.

PubMed Abstract | Publisher Full Text

122. Fleiss B, Tann CJ, Degos V, et al:: Inflammation-induced sensitization of the brain in term infants. Dev Med Child Neurol. 2015; 57(Suppl 3): 17-28. PubMed Abstract | Publisher Full Text

123. Wolfs TG, Kramer BW, Thuijls G, et al:: Chorioamnionitis-induced fetal gut injury is mediated by direct gut exposure of inflammatory mediators or by lung inflammation. Am J Physiol Gastrointest Liver Physiol. 2014; 306(5): G382-93. PubMed Abstract | Publisher Full Text | Free Full Text

124. Ng PY, Ireland DJ, Keelan JA: Drugs to block cytokine signaling for the prevention and treatment of inflammation-induced preterm birth. Front Immunol. 2015; 6: 166.

PubMed Abstract | Publisher Full Text | Free Full Text

125. Ireland DJ, Kemp MW, Miura Y, et al: Intra-amniotic pharmacological blockade of inflammatory signalling pathways in an ovine chorioamnionitis model. $\mathrm{MO}$ Hum Reprod. 2015; 21(5): 479-89. PubMed Abstract | Publisher Full Text

126. Ireland DJ, Nathan EA, Li S, et al: Preclinical evaluation of drugs to block inflammation-driven preterm birth. Innate Immun. 2017; 23(1): 20-33. PubMed Abstract | Publisher Full Text

127. F Hutchinson MR, Zhang $\mathrm{Y}$, Brown $\mathrm{K}$, et al:: Non-stereoselective reversal of neuropathic pain by naloxone and naltrexone: involvement of toll-like receptor 4 (TLR4). Eur J Neurosci. 2008; 28(1): 20-9. PubMed Abstract | Publisher Full Text | Free Full Text | F1000 Recommendation

128. Cheng W, Li Y, Hou X, et al:: HSP60 is involved in the neuroprotective effects of naloxone. Mol Med Rep. 2014; 10(4): 2172-6. PubMed Abstract | Publisher Full Text
129. Jiang $\mathrm{X}, \mathrm{Ni} \mathrm{Y}$, Liu T, et al.: Inhibition of LPS-induced retinal microglia activation by naloxone does not prevent photoreceptor death. Inflammation. 2013; 36(1): 42-52.

PubMed Abstract | Publisher Full Text

130. Wang TY, Su NY, Shih PC, et al.: Anti-inflammation effects of naloxone involve phosphoinositide 3-kinase delta and gamma. J Surg Res. 2014; 192(2): 599-606. PubMed Abstract | Publisher Full Text

131. Miller RR, Menke JA, Hansen NB, et al:: The effect of naloxone on the hemodynamics of the newborn piglet with septic shock. Pediatr Res. 1986; 20(8): 707-10.

PubMed Abstract | Publisher Full Text

132. Law WR, Ferguson JL: Naloxone alters organ perfusion during endotoxin shock in conscious rats. Am J Physiol. 1988; 255(5 Pt 2): H1106-13. PubMed Abstract

133. Wahid HH, Dorian CL, Chin PY, et al.: Toll-Like receptor 4 is an essential upstream regulator of on-time parturition and perinatal viability in mice. Endocrinology. 2015; 156(10): 3828-41. PubMed Abstract | Publisher Full Text | Free Full Text

134. F Chin PY, Dorian CL, Hutchinson MR, et al:: Novel Toll-like receptor-4 antagonist (+)-naloxone protects mice from inflammation-induced preterm birth. Sci Rep. 2016; 6: 36112

PubMed Abstract | Publisher Full Text | Free Full Text | F1000 Recommendation

135. Nadeau-Vallée M, Obari D, Quiniou C, et al:: A critical role of interleukin-1 in preterm labor. Cytokine Growth Factor Rev. 2016; 28: 37-51. PubMed Abstract | Publisher Full Text

136. Quiniou C, Sapieha $P$, Lahaie I, et al.: Development of a novel noncompetitive antagonist of IL-1 receptor. J Immunol. 2008; 180(10): 6977-87. PubMed Abstract | Publisher Full Text

137. F Nadeau-Vallée M, Quiniou C, Palacios J, et al:: Novel noncompetitive IL-1 receptor-biased ligand prevents infection- and inflammation-induced preterm birth. J Immunol. 2015; 195(7): 3402-15. PubMed Abstract | Publisher Full Text | F1000 Recommendation

138. F Nadeau-Vallée M, Chin PY, Belarbi L, et al.: Antenatal Suppression of IL-1 Protects against Inflammation-Induced Fetal Injury and Improves Neonatal and Developmental Outcomes in Mice. J Immunol. 2017; 198(5): 2047-62. PubMed Abstract | Publisher Full Text | F1000 Recommendation

139. Girardi G: Can statins prevent pregnancy complications? J Reprod Immunol. 2014; 101-102: 161-7. PubMed Abstract | Publisher Full Text

140. F Gonzalez JM, Pedroni SM, Girardi G: Statins prevent cervical remodeling, myometrial contractions and preterm labor through a mechanism that involves hemoxygenase-1 and complement inhibition. Mol Hum Reprod. 2014; 20(6): 579-89. PubMed Abstract | Publisher Full Text | F1000 Recommendation

141. Basraon SK, Menon R, Makhlouf M, et al:: Can statins reduce the inflammatory response associated with preterm birth in an animal model? Am J Obstet Gynecol. 2012; 207(3): 224.e1-7. PubMed Abstract | Publisher Full Text

142. F Basraon SK, Costantine MM, Saade G, et al.: The effect of Simvastatin on infection-induced inflammatory response of human fetal membranes. $A m \mathrm{~J}$ Reprod Immunol. 2015; 74(1): 54-61. PubMed Abstract | Publisher Full Text | F1000 Recommendation

143. Zarek J, Koren G: The fetal safety of statins: a systematic review and metaanalysis. J Obstet Gynaecol Can. 2014; 36(6): 506-9. PubMed Abstract | Publisher Full Text

144. Kazmin A, Garcia-Bournissen F, Koren G: Risks of statin use during pregnancy: a systematic review. J Obstet Gynaecol Can. 2007; 29(11): 906-8. PubMed Abstract | Publisher Full Text

145. Meher S, Alfirevic Z: Choice of primary outcomes in randomised trials and systematic reviews evaluating interventions for preterm birth prevention: a systematic review. BJOG. 2014; 121(10): 1188-94; discussion 1195-6. PubMed Abstract | Publisher Full Text

146. Khan K, O'Donovan P, Chief Editors of Journals participating in The CROWN Initiative: The CROWN initiative: journal editors invite researchers to develop core outcomes in women's health. BMC Pregnancy Childbirth. 2014; 14: 199. PubMed Abstract | Publisher Full Text | Free Full Text

147. van 't Hooft J, Duffy JM, Daly M, et al.: A Core Outcome Set for evaluation of interventions to prevent preterm birth. Obstet Gynecol. 2016; 127(1): 49-58. PubMed Abstract | Publisher Full Text 


\section{Open Peer Review}

\section{Current Peer Review Status:}

\section{Editorial Note on the Review Process}

Faculty Reviews are review articles written by the prestigious Members of Faculty Opinions. The articles are commissioned and peer reviewed before publication to ensure that the final, published version is comprehensive and accessible. The reviewers who approved the final version are listed with their names and affiliations.

\section{The reviewers who approved this article are:}

\section{Version 1}

\section{Louis Muglia}

${ }^{1}$ Center for Prevention of Preterm Birth and Division of Human Genetics, Cincinnati Children's Hospital Medical Center, Cincinnati, OH, USA

2 Department of Pediatrics, University of Cincinnati College of Medicine, Cincinnati, OH, USA Competing Interests: No competing interests were disclosed.

\section{Martijn A Oudijk}

Departments of Obstetrics and Gynecology, Academic Medical Centre, Amsterdam, The Netherlands Competing Interests: No competing interests were disclosed.

The benefits of publishing with F1000Research:

- Your article is published within days, with no editorial bias

- You can publish traditional articles, null/negative results, case reports, data notes and more

- The peer review process is transparent and collaborative

- Your article is indexed in PubMed after passing peer review

- Dedicated customer support at every stage

For pre-submission enquiries, contact research@f1000.com 